DOI: 10.32999/ksu2524-0838/2020-29-1

УДК 576.32/.36:544.277

Височанська М. В., Бесчасний С. П., Гасюк О. М.

ОЦІНКА ВПЛИВУ ДОНОРА МОНООКСИДУ КАРБОНУ (CORM-2) НА ШВИДКІСТЬ ЗГОРТАННЯ КРОВІ В УМОВАХ ІМУННОЇ ВІДПОВІДІ

\author{
Херсонський державний університет, Херсон, Україна \\ e-mail: beschasnyis@gmail.com
}

Баланс між підтримкою рідкого стану та прочесом тромбоутворення обумовлений активністю плазмових факторів та тромбоцитів. Тромбоцити, за умов пошкодження судин, спричиняють утворення тромбоциттарної пробки, вазоконстрикиію та у подальшому - беруть участь у відновленні тканин. Зниження активності згортальної функиії тромбоцитів $\epsilon$ актуальною проблемою, а пошук засобів - модуляторів активності тромбоцитів є перспективним напрямком дослідження. На увагу заслуговує використання сполук-газотрансмітерів для модулювання активності тромбоиитарної ланки гемостазу. Зокрема, монооксид карбону (СО) також належить до иієї групи. СО у наднизьких концентрачіях спричиняє різноманітні впливи на прочеси апоптозу, стимулює $\mathrm{Ca}^{2+}$ залежні K-канали, змінює активність мітохондрій. Для дослідження впливу СО на швидкість згортання крові лабораторним мишам уводили сполуку-донор CO (CORM-2) окремо під час індуктивної та продуктивної фази імунної відповіді. Контроль динаміки імунної відповіді здійснювали за показниками рівнів $\operatorname{IgA}$, IgM ma $\operatorname{IgG.~3'ясовано,~щзо~}$ згортання крові під впливом CORM-2 (у дозі 20 мг/кг) посилювалося, особливо у період продуктивної фази. Наприкінці експерименту у кістковому мозку досліджуваних груп, яким уводився CORM-2, спостерігалося зниження відсоткового вмісту мегакаріобластів у загальній популячії попередників тромбочитів. На иъьому тлі було виявлено збільшений вміст мегакаріоцитів у групі, яка отримувала CORM-2 під час розвитку продуктивної фази імунної відповіді. У групі, якій уводили CORM-2 під час індуктивної фази, окрім збільшення рівня мегакаріоцитів спостерігалося збільшення рівня тромбоцитів. У групі, яка отримувала CORM-2 у ичю фазу, також було зафіксовано переважання метамегакаріоцитів, зниження кількості тромбоцитів.

Ключові слова: тромбочити, донор монооксиду карбону, CORM-2, фази імунної вidnoвidi.

M. V. Vysochanska, S. P. Beschasnyi, O. M. Hasiuk

\title{
ASSESSMENT OF THE EFFECT OF CARBON MONOXIDE DONOR (CORM-2) ON BLOOD CLOTTING RATE UNDER CONDITIONS OF IMMUNE RESPONSE
}

The balance between the liquid state support of the blood and the thrombus formation process depends on the activity of plasma factors and thrombocytes. In a vascular injury condition, thrombocytes form a thrombocyte plug, vasoconstriction and, further, take part in the restoration of the tissues. Reducing the clotting function of thrombocytes is a current problem. The search for agents - modulators of thrombocyte activity - is a promising area of research. Compounds - gas-transmitters can be used to model the activity of thrombocytes hemostasis. 
Carbon monoxide (CO) gas belongs to this group as well. CO in very low concentrations affects in a different way the process of apoptosis, stimulates calcium-dependent potassium channels, and changes the activity of mitochondria. To investigate the effect of $C O$ on blood clotting rate, laboratory mice were injected with the compound CO donor (CORM-2). This substance was administered separately during the inductive and productive phases of the immune response. The dynamics of the immune response were measured by IgA, IgM and IgG immunoglobulin levels. It was found that blood clotting was intensified under the influence of CORM-2 (20 mg/kg). Especially, the increase was during the productive phase. At the end of the experiment, the percentage of megakaryoblasts in the total population of thrombocyte precursors decreased in the bone marrow of animals (to which CORM-2 was administered). Against this background, an increased content of megakaryocytes was found in the group that received CORM-2 during the productive phase. In the group that received CORM-2 during the inductive phase, in addition to an increase in megakaryocyte levels, there was an increase in thrombocyte levels. The group that received CORM-2 during the productive phase also had a predominance of metamegakaryocytes and reducing of thrombocyte amount.

Key words: thrombocytes, carbon monoxide donor, CORM-2, immune response phases.

Гемостаз являє собою фізіологічний процес своєрідного балансування між процесами підтримки рідкого стану крові та тромбоутворення. Ця система $є$ складною, динамічною компонентою, яка складається з пов'язаних між собою плазмових факторів та клітин - тромбоцитів [14, 17].

In vivo тромбоцити виконують ряд важливих функцій: утворення тромбоцитарної пробки за рахунок адгезії та агрегації тромбоцитів; продукція вазоконстрикторів для зниження кровотоку в ушкодженій ділянці; активація гуморальної згортальної ланки 3 подальшим утворенням фібринового згустку; ініціація відновлення тканин [16].

За відсутності стимуляції тромбоцити мають незначну метаболічну активність, не взаємодіють з іншими клітинами крові, ендотеліальними клітинами судинного русла [1, 15]. Окрім надмірної згортальної активності крові, існує проблема зниженої тромбоцитарної функції, поява кровоточивості тощо [16].

Модулювання згортальної функції крові все ще залишається актуальною проблемою, тому дослідження перспективних сполук - модуляторів гемостазу $\epsilon$ актуальною темою. Одним із таких претендентів $\epsilon$ представник групи газотрансмітерів монооксид карбону (СО) $[4,10]$. СО відомий як отруйний газ, проте у 1968 році Tenhunen et al. повідомили, що цей газ утворюється в організмі під час розпаду гема. Після цього почався період вивчення фізіологічних ефектів СО [8]. На сьогодні відомо, що СО у пікомолярній кількості здатен пригнічувати апоптоз клітин $[3,5,13]$, стимулює $\mathrm{Ca}^{2+}$ залежні К-канали [7], чинить вплив на активність мітохондрій [9].

Єдиною проблемою для застосування СО було те, що дозування цього газу складно проводити, можливі отруєння. У зв'язку із цим подальші дослідження терапевтичних впливів СО загальмувалися. Цю проблему було вирішено шляхом створення сполук донорів СО [11]. Після уведення до організму такої сполуки відбувається повільне вивільнення СО у незначних, контрольованих кількостях.

Одним із представників цих сполук є CORM-2 (tricarbonyldichlororuthenium (II) dimer), основою якого є карбонільна сполука рутенію. Доведено, що CORM-2 володіє антиоксидантною активністю в плазмі [2], прискорює загоєння виразки шлунку [10], регулює проникність мембрани мітохондрій [12], впливає на тривалість клітинного циклу 
[4]. Зазначене підтверджує актуальність дослідження донора СО та вплив цієї сполуки на кістковий мозок і продукцію імуноглобулінів в умовах антигенної стимуляції.

Мета роботи полягає у виявленні впливу CORM-2 на швидкість згортання крові та вміст попередників тромбоцитів у кістковому мозку мишей в процесі індукції імунної відповіді.

\section{МАТЕРІАЛИ І МЕТОДИ}

Дослідження проведено на білих безпородних лабораторних мишах масою $22 \pm 3$ г. Було сформовано 3 експериментальні групи по 15 самців кожна. Усім тваринам для індукції імунної відповіді внутрішньоочеревинно уводили еритроцити барана (ЕБ) (Фармстандарт Біолек, Україна) у дозі 100 клітин на 1 кг маси тіла. Першій експериментальній групі у період індуктивної фази (в один день імунізації ЕБ) уводився CORM-2 (доза 20 мг/кг), розчинений у диметилсульфоксиді (ДМСО) та фізіологічному розчині (ФР). Тваринам другої експериментальної групи уводили такий самий розчин, але в період продуктивної фази (5-й день після імунізації). Контрольну групу склали 15 самців білих мишей, які також були імунізовані, але не отримували CORM-2.

Для контролю розвитку імунної відповіді проводили визначення кількості імуноглобулінів IgA, IgM та IgG із використанням набору для імуноферментного аналізу (НВЛ «Гранум», Україна). Детекцію результатів дослідження проводили за допомогою IФA аналізатора Immunohem-21100, HTI (USA) на 2-й та на 6-й день після імунізації. Швидкість згортання крові визначали за методом Lee-White шляхом реєстрації перших ознак утворення кров'яного згустку у часовому склі інкубованого за температури $37^{0} \mathrm{C}$ [6].

Наприкінці експерименту (6-та доба) проводили евтаназію шляхом передозування ізофлурану. Виокремлювали стегнові кістки та робили відбитки кісткового мозку. Отримані відбитки забарвлювали за методом Романовського-Гімзи та здійснювали облік кількості клітин кісткового мозку за допомогою мікроскопа.

Усі процедури з лабораторними тваринами проводилися із дотриманням дерективи Ради Свропи ЄC 2010/63/EU та були схвалені біоетичною комісією. Статистичну обробку проводили із використанням критеріїв Мана-Уїтні та Вілкоксона. При цьому достовірним вважали результат при $\mathrm{p} \leq 0,5$. Ступінь взаємозв'язків показників розраховували за допомогою коефіцієнта кореляції Пірсона.

\section{РЕЗУЛЬТАТИ ТА ЇХ ОБГОВОРЕННЯ}

Як відомо, процес згортання крові відіграє важливу гемостатичну функцію в організмі, попереджаючи крововтрату та поширення хвороботворних організмів по судинному руслу. Разом з тим, ураження печінки, потрапляння гемотоксичних отрут, геморагічні лихоманки, аутоімунні процеси здатні обумовлювати зниження процесів згортання крові $[6,16]$.

Дослідження показало певні особливості впливу донора монооксиду карбону (CO) на швидкість згортання крові за умов розвитку імунної відповіді. Контроль розвитку імунної відповіді демонструє графік вмісту імуноглобулінів у сироватці крові (рис. 1). 


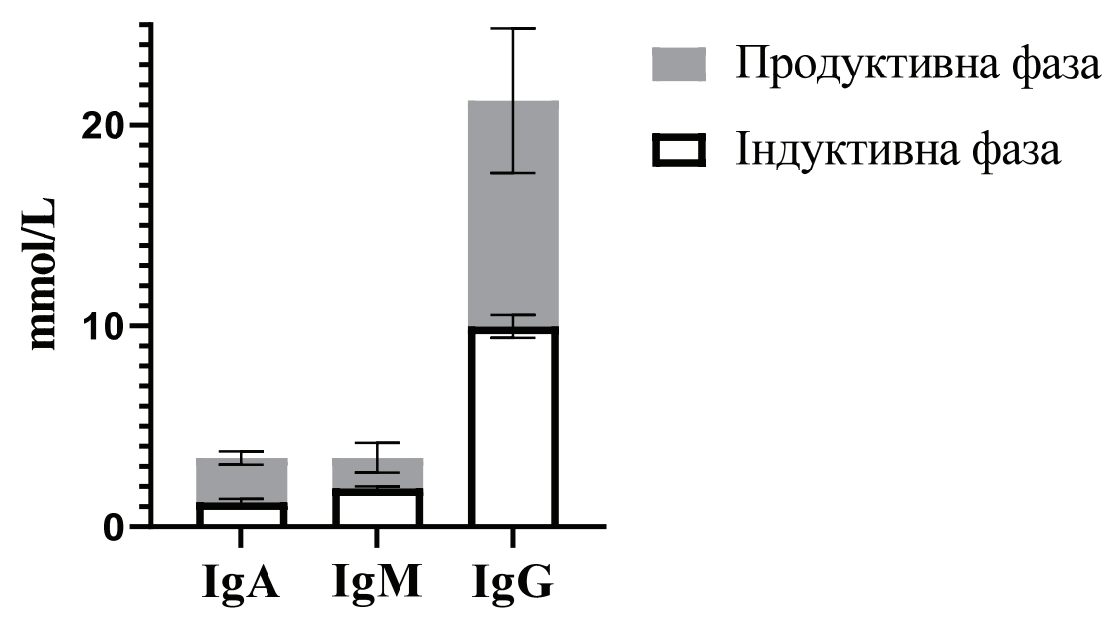

Рис. 1. Середнс значення концентрації імуноглобулінів у периферичній крові досліджуваних груп у різні фази імунної відповіді

Відповідно, спостерігається підвищення концентрації $\mathrm{IgG}$, що вказує на розвиток імунної відповіді. Порівняння середніх показників швидкості згортання крові продемонструвало вплив уведення CORM-2 на систему гемостазу (рис. 2).

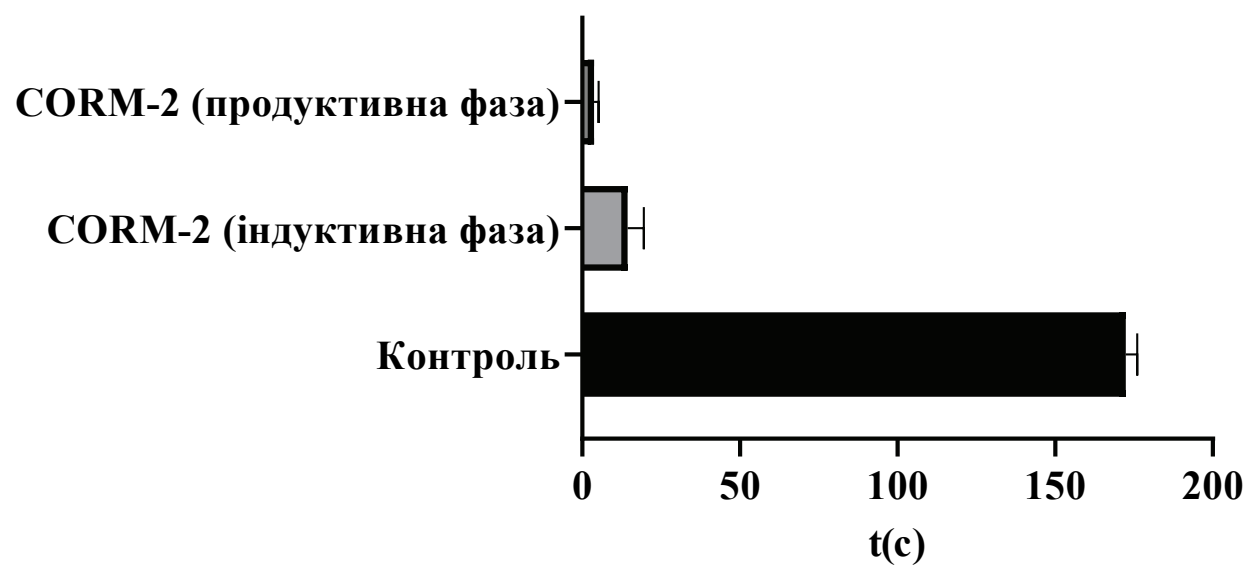

Рис. 2. Швидкість часу згортання крові після введення CORM-2 у різні фази імунної відповіді

Зокрема, час швидкості згортання крові у групі, якій уводили CORM-2 в індуктивну фазу імунної відповіді, зменшився на $86 \pm 5,8$ \%. У групі, якій уводили CORM-2 під час періоду продуктивної фази, час згортання крові знизився на $96 \pm 5,2 \%$ у порівнянні 3 контрольною групою. Як можна побачити з рисунку 2, уведення донора монооксиду карбону під час формування продуктивної фази імунної відповіді обумовлює зменшення часу згортання крові у досліджуваній групі тварин.

Цікавим виявилися показники вмісту тромбоцитів та їх попередників у червоному кістковому мозку (рис. 3). 


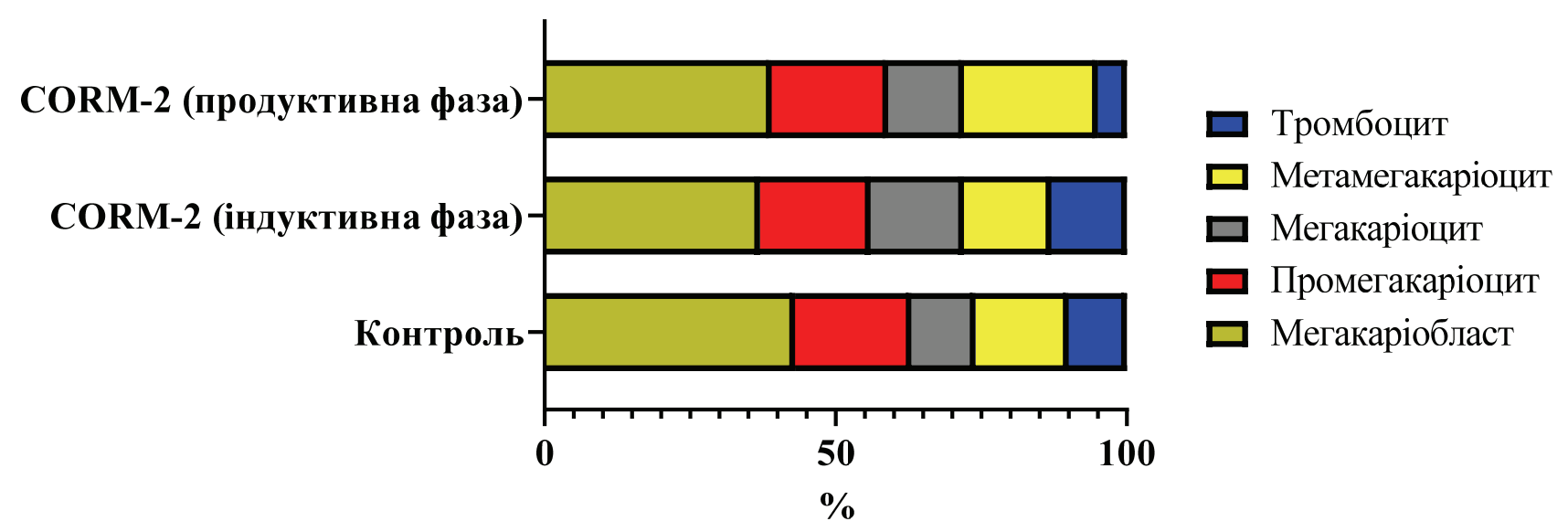

Рис. 3. Відсоткове співвідношення попередників тромбоцитів у червоному кістковому мозку тварин досліджуваних груп

У кістковому мозку досліджуваних груп, яким уводився CORM-2 (у порівнянні з контрольною групою) спостерігалося зниження відсоткового вмісту мегакаріобластів у загальній популяції попередників тромбоцитів. На цьому тлі було виявлено збільшений вміст мегакаріоцитів у групі, яка отримувала CORM-2 в період індуктивної та продуктивної фаз імунної відповіді.

У групі, яка отримувала CORM-2 у індуктивну фазу (на початку експерименту), окрім збільшення відсоткового вмісту мегакаріоцитів спостерігалося й збільшення вмісту тромбоцитів. У групі, яка отримувала CORM-2 у продуктивну фазу, було зафіксовано збільшення відсоткового вмісту метамегакаріоцитів та знижено кількість тромбоцитів.

Дослідження взаємозв'язків між часом згортання крові та вмістом попередників тромбоцитів у кістковому мозку показало найбільшу кількість кореляцій в групі, якій уводили CORM-2 у продуктивний період імунної відповіді (таблиця). У цій групі була встановлена найбільша кількість зворотних зв'язків. У групі тварин, які отримували донор монооксиду карбону в індуктивну фазу, спостерігалося переважання прямих кореляційних зв'язків.

Таблиия

Кореляційні зв'язки між показниками вмісту окремих груп попередників тромбоцитів та швидкістю згортання крові у досліджуваних групах

\begin{tabular}{|l|c|c|c|}
\hline & $\begin{array}{c}\text { Контрольна } \\
\text { група }\end{array}$ & $\begin{array}{c}\text { СОRM-2 } \\
\text { індуктивна } \\
\text { фаза }\end{array}$ & $\begin{array}{c}\text { СОRM-2 } \\
\text { продуктивна } \\
\text { фаза }\end{array}$ \\
\hline Мегакаріобласт & 0,3 & 0 & $\mathbf{- 0 , 6}$ \\
\hline Промегакаріоцит & 0,1 & 0,3 & $\mathbf{- 0 , 7}$ \\
\hline Мегакаріоцит & 0,3 & 0,7 & 1,0 \\
\hline Метамегакаріоцит & 0,4 & $\mathbf{- 0 , 5}$ & $\mathbf{- 0 , 2}$ \\
\hline Тромбоцит & 0,2 & 0,6 & 1,0 \\
\hline
\end{tabular}

Отже, в групі, яка отримувала CORM-2 під час індуктивної фази імунної відповіді, сильний прямий зв'язок спостерігався між швидкістю згортання крові та кількістю мегакаріоцитів, значний прямий зв'язок спостерігався 3 кількістю тромбоцитів, 3 
показником кількості метамегакаріоцитів виявлено значний зворотній зв'язок. В групі, яка отримувала CORM-2 під час продуктивної фази, прямий функціональний зв'язок встановлено із кількістю мегакаріоцитів і тромбоцитів. Зворотній сильний зв'язок виявлено із кількістю промегакаріоцитів, а 3 кількістю мегакаріобластів - значний зворотній зв'язок.

\section{ВИСНОВКИ}

Отримані результати вказують на те, що CORM-2 у дозі 20 мг/кг посилює згортання крові у лабораторних тварин в умовах імунної відповіді. Максимальне посилення спостерігалося після уведення CORM-2 у продуктивний період. Беззаперечним є те, що розвиток імунної відповіді може прискорювати згортання крові, проте у контрольній групі зазначене явище не спостерігалося (незважаючи на те, що тварини цієї групи також були імунізовані).

Донор монооксиду карбону CORM-2 впливає на процеси згортання крові незважаючи на його протизапальні властивості. Разом 3 тим, уведення цієї сполуки спричиняє зміну відсоткового вмісту попередників тромбоцитів у кістковому мозку: знижує кількість мегакаріобластів, збільшує кількість мегакаріоцитів та тромбоцитів у випадку введення CORM-2 під час індуктивної фази імунної відповіді. Введення CORM-2 у фазу продуктивної імунної відповіді спричиняє збільшення рівня метамегакаріоцитів.

\section{ЛІТЕРАТУРА}

1. Гасюк ОМ, Речицький $\mathrm{OH}$, Бесчасний СП. Активність мієлопероксидази лейкоцитів білих мишей за умови впливу спірокарбону. Теорія і практика сучасного природознавства: V Всеукр. наук, -практ. конф; 2011; Херсон, ПП Вишимирський В.С.; С.28-32.

2. Adach W, Olas B. The role of CORM-2 as a modulator of oxidative stress and hemostatic parameters of human plasma in vitro. PLoS One. 2017;12(9):e0184787

3. Bilban M, Bach FH, Otterbein SL, Ifedigbo E, d'Avila JC, Esterbauer H, Chin BY, Usheva A, Robson SC, Wagner O, Otterbein LE. Carbon monoxide orchestrates a protective response through PPARgamma. Immunity. 2006;24:601-610. DOI: https://doi.org/10.1016/j.immuni.2006.03.012

4. Brouard S, Otterbein LE, Anrather J, Tobiasch E, Bach FH, Choi AM, Soares MP. Carbon monoxide generated by heme oxygenase-1 suppresses endothelial cell apoptosis. J Exp Med. 2000;192(7):1015-1026. DOI: 10.1084/jem.192.7.1015

5. Balasubramanian A, MacIntyre NR, Henderson RJ, Jensen RL, Kinney G, Stringer WW \& Porszasz J. Diffusing capacity of carbon monoxide in assessment of COPD. Chest. 2019;156(6):1111-1119. DOI: https://doi.org/10.1016/j.chest.2019.06.035

6. Briggs $\mathrm{C}$, et al. "ICSH Guideline for worldwide point of care testing in haematology with special reference to the complete blood count". International journal of laboratory hematology. 2008;30.2:105-116.

7. Beschasnyi S, Hasiuk O. CO-Releasing Molecule (CORM-2) in the regulation of $\mathrm{Ca}^{2+}$ dependent $\mathrm{K}^{+}$-permeability of erythrocyte. JMBS. 2020;5(2):166-171. DOI: https://doi.org/10.26693/jmbs05.02.166

8. Coburn RF, Blakemore WS, Forster RE. Endogenous carbon monoxide production in man. J Clin Invest.1964;42:1172-1178.

9. Juszczak Michał, et al. DNA damage and antioxidant properties of CORM-2 in normal and cancer cells. Scientific Reports. 2020;10.1: 1-12. DOI: https://doi.org/10.1038/s41598-020-68948-6 
10. Magierowska K, Magierowski M, Hubalewska Mazgaj M, Sliwowski Z, Ginter G. Carbon monoxide released from its pharmacological donor, tricarbonyldichlororuthenium (II) dimer, accelerates the healing of preexisting gastric ulcers. Br J Pharmacol. 2017;174(20):3654-3668. DOI: 10.1111/bph.13968.

11. Rose JJ, Wang L, Xu Q, Mc Tiernan CF, Shiva S. Carbon monoxide poisoning: pathogenesis, management, and future directions of therapy. Am J Respir Crit Care Med. 2017;195(5):596-606. DOI: 10.1164/rccm.201606-1275CI.

12. Ryter SW, Alam J, Choi AM. Heme oxygenase-1/carbon monoxide: from basic science to therapeutic applications. Physiol. Rev. 2006;86:583-650. DOI: 10.1152/physrev.00011.2005.

13. Sener A, Tran K, Deng JP, et al. Carbon monoxide releasing molecules inhibit cell death resulting from renal transplantation related stress. J. Urol. 2013;190: 772-778. DOI: 10.1016/j.juro.2012.12.020.

14. Sokolenko VL, Sokolenko SV. Manifestations of allostatic load in residents of radiation contaminated areas aged 18-24 years. Regulatory Mechanisms in Biosystems. 2019;10(4):422-431. DOI: https://doi.org/10.15421/021963

15. Sokolenko VL, Sokolenko SV. Parameters of lipid and oxidative-antioxidant status in persons aged 18-23 from radiation-contaminated areas under conditions of moderate physical activity. Physical Education of Students. 2020;24(5):293-303. DOI: https://doi.org/10.15561/20755279.2020.0506

16. Song AB, David J Kuter, Hanny Al Samkari. Characterization of the rate, predictors, and thrombotic complications of thrombocytosis in iron deficiency anemia. American Journal of Hematology. 2020;95.10:1180-1186.

17. Vo, Quyen T, Dennis F Thompson. A review and assessment of drug-induced thrombocytosis. Annals of Pharmacotherapy. 2019;53.5: 523-536.

\section{REFERENCES}

1. Hasiuk OM, Rechytskyi ON, Beschasnyi SP. Aktyvnist miieloperoksydazy leikotsytiv bilykh myshei za umovy vplyvu spirokarbonu. Teoriia i praktyka suchasnoho pryrodoznavstva: V Vseukr. nauk, -prakt. konf; 2011; Kherson, PP Vyshymyrskyi B.C.; S.28-32. [in Ukrainian]

2. Adach W, Olas B. The role of CORM-2 as a modulator of oxidative stress and hemostatic parameters of human plasma in vitro. PLoS One. 2017;12(9):e0184787

3. Bilban M, Bach FH, Otterbein SL, Ifedigbo E, d'Avila JC, Esterbauer H, Chin BY, Usheva A, Robson SC, Wagner O, Otterbein LE. Carbon monoxide orchestrates a protective response through PPARgamma. Immunity. 2006;24:601-610. DOI: https://doi.org/10.1016/j.immuni.2006.03.012

4. Brouard S, Otterbein LE, Anrather J, Tobiasch E, Bach FH, Choi AM, Soares MP. Carbon monoxide generated by heme oxygenase-1 suppresses endothelial cell apoptosis. J Exp Med. 2000;192(7):1015-1026. DOI: 10.1084/jem.192.7.1015

5. Balasubramanian A, MacIntyre NR, Henderson RJ, Jensen RL, Kinney G, Stringer WW \& Porszasz J. Diffusing capacity of carbon monoxide in assessment of COPD. Chest. 2019;156(6):1111-1119. DOI: https://doi.org/10.1016/j.chest.2019.06.035

6. Briggs $\mathrm{C}$, et al. "ICSH Guideline for worldwide point of care testing in haematology with special reference to the complete blood count". International journal of laboratory hematology. 2008;30.2:105-116. 
7. Beschasnyi S, Hasiuk O. CO-Releasing Molecule (CORM-2) in the regulation of $\mathrm{Ca}^{2+}$ dependent $\mathrm{K}^{+}$-permeability of erythrocyte. JMBS. 2020;5(2):166-171. DOI: https://doi.org/10.26693/jmbs05.02.166

8. Coburn RF, Blakemore WS, Forster RE. Endogenous carbon monoxide production in man. J Clin Invest.1964;42:1172-1178.

9. Juszczak Michał, et al. DNA damage and antioxidant properties of CORM-2 in normal and cancer cells. Scientific Reports. 2020;10.1: 1-12. DOI: https://doi.org/10.1038/s41598-020-68948-6

10. Magierowska K, Magierowski M, Hubalewska Mazgaj M, Sliwowski Z, Ginter G. Carbon monoxide released from its pharmacological donor, tricarbonyldichlororuthenium (II) dimer, accelerates the healing of preexisting gastric ulcers. Br J Pharmacol. 2017;174(20):3654-3668. DOI: 10.1111/bph.13968.

11. Rose JJ, Wang L, Xu Q, Mc Tiernan CF, Shiva S. Carbon monoxide poisoning: pathogenesis, management, and future directions of therapy. Am J Respir Crit Care Med. 2017;195(5):596-606. DOI: 10.1164/rccm.201606-1275CI.

12. Ryter SW, Alam J, Choi AM. Heme oxygenase-1/carbon monoxide: from basic science to therapeutic applications. Physiol. Rev. 2006;86:583-650. DOI: 10.1152/physrev.00011.2005.

13. Sener A, Tran K, Deng JP, et al. Carbon monoxide releasing molecules inhibit cell death resulting from renal transplantation related stress. J. Urol. 2013;190: 772-778. DOI: 10.1016/j.juro.2012.12.020.

14. Sokolenko VL, Sokolenko SV. Manifestations of allostatic load in residents of radiation contaminated areas aged 18-24 years. Regulatory Mechanisms in Biosystems. 2019;10(4):422-431. DOI: https://doi.org/10.15421/021963

15. Sokolenko VL, Sokolenko SV. Parameters of lipid and oxidative-antioxidant status in persons aged 18-23 from radiation-contaminated areas under conditions of moderate physical activity. Physical Education of Students. 2020;24(5):293-303. DOI: https://doi.org/10.15561/20755279.2020.0506

16. Song AB, David J Kuter, Hanny Al Samkari. Characterization of the rate, predictors, and thrombotic complications of thrombocytosis in iron deficiency anemia. American Journal of Hematology. 2020;95.10:1180-1186.

17. Vo, Quyen T, Dennis F Thompson. A review and assessment of drug-induced thrombocytosis. Annals of Pharmacotherapy. 2019;53.5: 523-536.

Стаття надійшла до редакиіï 28.10.2020.

The article was received 28 October 2020. 